DOI: $10.15421 / 272008$

УДК 030

\title{
В. Оноприенко
}

Институт исследований научно-технического потенциала и истории науки им. Г. М. Доброва НАН Украинь, г. Киев, Украина

\section{СТРЕМЛЕНИЕ К ВЕРШИНАМ (К юбилею Г. П. Матвиевской)}

E-mail: valonopr@gmail.com

\begin{abstract}
Аннотация. Воссозданы этапы и вехи творческого пути выдающегося историка математики академика Академии наук Узбекистана и действительного члена Международной академии истории науки Г. П. Матвиевской, эволюция тематики исследований и десятки книг, внесших вклад в мировую науку. Важное место в исследованиях заняла работа над архивным собранием великого математика Леонарда Эйлера для издания полного собрания его сочинений. Изучив латынь и арабский язык, Матвиевская принялась расшифровывать рукописи великих арабских учёных Улугбека, Ал-Хорезми, «Трактат о соизмеримых и несоизмеримых величинах» математика X-XI вв. Ибн ал-Багдади. За этим последовали другие арабские трактаты о теории квадратичных иррациональностей. Их переводы вошли в её книгу «Учение о числе на средневековом Ближнем и Среднем Востоке», которая вышла в 1967 г. За ней последовали работы по истории математики в средневековой Европе. К середине XX в. укоренилось мнение, что арабы успешно разрабатывали новые вычислительные приемы, но теоретического наследия древних греков они вообще не освоили. Заслугу их видели в том, что они перевели труды греческих классиков на арабский язык, сохранив их таким образом от забвения, а затем передали их в Европу, где эти труды были осмыслены и послужили стимулом быстрого развития математической теории. Матвиевской удалось существенно скорректировать такой стереотип: ей удалось показать, что учёные стран Ближнего и Среднего Востока не только хорошо поняли все тонкости античного учения о числе, но и существенно его развили. Она автор многих книг о математических достижениях А. Дюрера, Рамуса, Р. Декарта, советских математиков В. И. Смирнова, В. И. Романовского и других. С 1994 г. живёт и трудится в Оренбурге, перешла к разработке богатого архивного наследия Оренбуржья. Завершила и опубликовала книгу отца о первом члене-корреспонденте Петербургской академии наук Петре Рычкове, свои книги краеведческого содержания о Владимире Дале и Якове Ханыкове. Опубликован курс лекций «История математики». Она стала членом Союза писателей России, удостоена литературных премий.
\end{abstract}

Ключевые слова: теория чисел, математические идеи и достижения средневековых арабских математиков и учёных Европы, научная биографистика, историческое краеведение.

\section{Onoprienko}

G.M. Dobrov Institute for Scientific and Technical Potential and Science History Studies of the NAS of Ukraine, Kiyv, Ukraine

\section{STRIVING TO THE TOPS (to an anniversary of G. P. Matvievskaya)}

Absract. It is recreated stages and milestones of the creative development of G.P. Matvievskaya, an outstanding historian of mathematics, academician of the Academy of 
Sciences of Uzbekistan and full member of the International Academy of the History of Science, an evolution of research topics and dozens of books that have contributed to global science. Major research focus was taken by the work on archival collection of a great mathematician Leonard Euler for publication of his complete works. Having studied Latin and Arabic, Matvievskaya began to interpret the manuscripts of the great Arab scholars Ulugbek, Al-Khorezmi, "A treatise on commensurate and disproportionate quantities" of Ibn al-Baghdadi. This was followed by other Arabic treatises on theory of quadratic irrationalities. Their translations were included in her book "The Doctrine of Number in the Medieval Near and Middle East", which was published in 1967. It was followed by the works on the history of mathematics in medieval Europe. By the mid20th century it was entrenched an opinion that Arabs successfully developed new computational techniques, but they did not master theoretical heritage of the ancient Greeks at all. Their merit was seen in translation of the works of Greek classics into Arabic, keeping them from oblivion, and then they were transmitted to Europe, where were comprehended and acted as a spur to the rapid development of mathematical theory. Matvievskaya was able substantially to adjust the stereotype: she showed that scientists from the countries in the Near and Middle East not only comprehended all the subtleties of ancient doctrine of numbers, but also significantly developed it. She is the author of numerous books on mathematical achievements of A. Durer, Ramus, R. Descartes, Soviet mathematicians V.I. Smirnov, V.I. Romanovsky and others. Since 1994 she has been living and working in Orenburg, has proceeded to the development of the rich archival heritage of the Orenburg region. She completed and published her father's book about the first corresponding member of the Saint Petersburg Academy of Sciences Peter Rychkov, her books on regional history about Vladimir Dal and Yakov Hanykov. It was published a course of lectures "History of Mathematics". She became a member of the Union of Writers of Russia, was awarded literary prizes.

Keywords: number theory, mathematical ideas and achievements of middle-aged Arab mathematicians and European scientists, scientific biography, regional history.

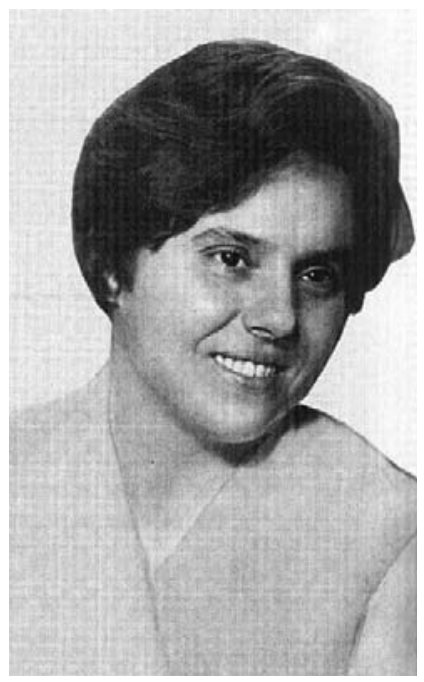

Вступление. Галина Павловна Матвиевская выдающийся историк математики, востоковед, доктор физико-математических наук (1969), заслуженный деятель науки Узбекской ССР (1980), действительный член Международной академии истории науки (1993), академик АН Узбекистана (2000).

Но исток многих её достижений и дарований находится в Днепропетровске (ныне - Днепр), где она родилась 13 июня 1930 г. Её отец Павел Евменович Матвиевский (1904-1987) родился в селе Бобрик Роменского района Полтавской губернии (теперь Сумскач область), был самым младшим в многодетной батрацкой семье, но с великой тягой к образованию: мальчиком был пастухом, окончил двухклассную земскую школу, в 1918 г. поступил в гимназию для взрослых (рабочую школу) в г. Ромны, которую окончил в 1921 г. Работал учителем семилетней школы в селе Великие Бубны Роменского района. В 1923 г. П. Е. Матвиевский поступил на историко-филологический факультет 
Днепропетровского института народного образования (так был назван реформированный в 20-е годы Екатеринославский университет). Учебу совмещал с работой: был учителем на курсах таксировщиков и весовщиков Екатеринославской железной дороги. На старших курсах был приглашен в Историко-археологический музей, директором которого был известный украинский ученый, академик АН УССР Д. И. Яворницкий. Под руководством Дмитрия Ивановича началась научная работа П. Е. Матвиевского, который со временем стал ученым секретарем музея. На знаменитой картине И. Е. Репина, где запорожцы пишут письмо турецкому султану, Яворницкий изображен писарем, поэтому Матвиевского называли писарем писаря. П. Е. Матвиевский - активный учасник историко-археологической экспедиции под руководством Д. И. Яворницкого, организованной в 1927 г. по решению Наркомпроса УССР на Днепрострое для исследования территории Запорожской Сечи, которая подлежала затоплению.

Детские годы Галины Матвиевской прошли в Харькове, тогдашней столице Украины. С 1931 г. П. Е. Матвиевский - научный сотрудник Харьковского научноисследовательского института истории культуры, старший научный сотрудник и заместитель директора по научной части Харьковского исторического музея. В 1931-1940 гг. он по совместительству работал преподавателем истории СССР и музееведения в Институте коммунистического образования в Харькове, а затем был заведующим учебной частью музейных курсов в Киеве, учёным секретарём Пушкинской выставки, старшим научным сотрудником Полтавского исторического музея. В Харькове он попал под массовый каток репрессий против украинской интеллигенции. Правда, с относительно счастливым исходом: ложность домыслов следствия обнаружилась, и он был освобождён. Чтобы не испытывать судьбу, он подал документы на должность доцента в Чкаловский педагогический институт и связал себя с ним навсегда. Он был деканом исторического факультета, проректором по научной работе, в течение долгих лет заведовал кафедрой истории СССР. В 1943 г. он защитил кандидатскую диссертацию, в 1946 г. был утвержден в звании доцента, а в 1966 г. - профессора.

Годы работы на Украине сформировали П. Е. Матвиевского как убеждённого историка с ориентацией на архивные источники, конечно, с учётом советских идеологических шаблонов. Это имело и важное значение для общекультурной и гуманитарной подготовки дочери, смолоду проявившей неординарные способности к математике. Девочка с яркой украинской внешностью целеустремлённо постигала математические дисциплины. Галина с матерью оставили Харьков только после быстрого наступления фашистов в 1941 г., отправившись с одним чемоданом в путь в Чкалов, до этого и ныне - Оренбург. Этот путь дорогами войны оказался длиной 17 суток. Она окончила школу в Чкалове с золотой медалью и поступила на математико-механический факультет Ленинградского университета. Выбор в пользу Ленинграда был сделан под влиянием матери, окончившей там гимназию и Герценовский институт. В Чкалове мать заведовала кафедрой в медицинском институте и преподавала иностранные языки.

Материал и методы исследования. Использован биографический метод с акцентом на реконструкцию научного вклада и варианты историографического исследования. Использован материал интервью с Г. П. Матвиевской. 
Результаты и обсуждение. Галина Матвиевская с воодушевлением занялась математикой. В Ленинградском университете оказался очень сильный курс, около половины студентов поступили с золотыми и серебряными медалями. Было много приезжих - со всех концов страны. Но главное, были замечательные преподаватели. Дифференциальное исчисление читал профессор Г. М. Фихтенгольц. Только что вышел из печати его трехтомный учебник, по которому несколько поколений советских студентов изучали математический анализ. Алгебраические курсы вёл профессор Д. К. Фаддеев, замечательный алгебраист и обаятельный человек, которого все студенты полюбили сразу и навсегда. Аналитическую геометрию читал Н. А. Шанин, а дифференциальную и основания геометрии - А. Д. Александров, тогда молодой член-корреспондент Академии наук, впоследствии академик, крупнейший геометр и философ, много занимавшийся историей математики. Патриарх ленинградской математической школы, академик В. И. Смирнов, автор пятитомного «Курса высшей математики», много раз переиздававшегося на русском и иностранных языках, читал курс интегральных уравнений. Фактически весь преподавательский корпус состоял из ярких личностей.

Галина училась самозабвенно и успешно. Она определилась со специализацией, ею стала теория чисел. Крупный специалист в этой области профессор Б. А. Венков стал руководителем её диплома, который она защитила с отличием. История математики в Ленинградском университете была поставлена очень высоко и серьёзно. Тем не менее специальностью Галины Павловны она стала совершенно неожиданно.

Именно в это время Владимир Иванович Смирнов начал заниматься рукописями Леонарда Эйлера, которые только что были возвращены в Архив Академии наук СССР из Швейцарии. Туда они были отправлены на время ещё в 1910 г., когда разрабатывался проект издания полного собрания сочинений («Opera omnia») великого математика. После войны, благодаря настойчивости С. И. Вавилова и других академиков, эти бесценные рукописи вернулись в Ленинград. Они вызвали всеобщий интерес, так как приближался 250-летний юбилей Эйлера, который готовились торжественно отметить в 1957 г. Владимир Иванович был одним из инициаторов работы по изучению его рукописного наследия. Он искал инициативного сотрудника в этом непростом деле.

Работая в архиве с рукописями Эйлера В. И. Смирнов понял, что огромный рукописный материал требует внимательного изучения, так как он может скрывать новые научные результаты, которые Эйлер получил, но никогда не публиковал, новые идеи, которые так и остались нереализованными. Творческая активность Эйлера была беспримерной: он написал более 700 сочинений по разным отраслям точных наук. Начатое после его 200-летнего юбилея издание «Opera omnia» продолжалось в течение всего XX века. Вышло 76 томов, но до неопубликованных рукописей дело еще не дошло. В. И. Смирнов выяснил, что около половины рукописного материала относится к теории чисел. Внимание его привлекли записные книжки - 12 томов разного объема, куда учёный на протяжении всей жизни вносил заметки научного содержания. Здесь он фиксировал полученные результаты, проверял гипотезы, набрасывал планы дальнейших исследований. В общем, это более 2000 страниц, исписанных формулами с редкими комментариями на латинском языке. Нужно затратить много труда, чтобы в них хоть как-то 
разобраться. Поскольку большая часть записей носила теоретико-числовой характер, Владимир Иванович привлёк к их исследованию Г.П. Матвиевскую.

В. И. Смирнов считал необходимым превратить Архив Академии наук в серьёзное научно-исследовательское учреждение и, став в 1948 г. председателем его учёного совета, сделал очень многое для того, чтобы это осуществилось.

С одной стороны, это было большое счастье работать с таким мастером как академик В. И. Смирнов, не только великий математик, но человек высокой культуры и ответственности, который великолепно владел европейскими языками и латынью. С другой стороны, уже первые требования для работы с рукописями Эйлера не могли не поставить в тупик. Матвиевская, конечно, неплохо была подготовлена мамой-филологом к европейским языкам, но оказалось, что этого тоже недостаточно.

Работа Г. П. Матвиевской с В. И. Смирновым началась в 1954 г., когда она поступила в аспирантуру Ленинградского отделения Института истории естествознания и техники АН СССР и стала, таким образом, историком математики. Тема диссертационной работы звучала так: «Неопубликованные рукописи Эйлера по теории чисел в Архиве АН СССР». Чтобы заняться этой необычной по тому времени темой, требовалось, прежде всего, большое желание. Оно у Матвиевской было. Но необходимо было знание языков. Немецкий язык она знала с детства. Но и здесь возникли немалые проблемы. Для подготовки к кандидатскому экзамену по истории математики Владимир Иванович предложил ей как основной источник четырехтомный немецкий курс истории математики Морица Кантора, по которому он сам в своё время изучал этот предмет. Теперь это сочинение считается классическим. Трудный текст иногда доводил Галину Павловну до слёз, но зато это была прекрасная школа: через некоторое время немецкие работы по истории математики она могла читать практически без словаря.

Эйлера нельзя было понять без знания латыни, поскольку он писал преимущественно по-латыни. В. И. Смирнов знал её превосходно, в молодости подрабатывал преподаванием латыни. Матвиевская занималась ею на академической кафедре иностранных языков, потом сдавала экзамен кандидатского минимума. Знание латыни позволили ей понимать математические тексты Эйлера.

При Ленинградском отделении ИИЕТ изучением рукописного наследия Эйлера начала заниматься под руководством В. И. Смирнова целая группа сотрудников. Составлялись каталоги рукописных материалов, расшифровывалась и готовилась к публикации переписка Эйлера с учёными. Над этим трудилась Татьяна Николаевна Кладо - замечательный исследователь, образованнейший человек, знаток иностранных языков. Очень активно работали молодые тогда латинисты Юдифь Ефимовна Копелевич и Татьяна Аркадьевна Красоткина (Лукина). Елена Петровна Ожигова, в то время уже защитившая кандидатскую диссертацию по теории чисел и преподававшая математику в Военной академии, в 1964 г. перешла на работу в ЛО ИИЕТ и до самой кончины в 1993 г. объединяла вокруг себя петербургских историков математики.

«В работе над диссертацией я столкнулась с большими трудностями. Материал по теории чисел в записных книжках Эйлера оказался таким огромным, что сначала я не знала, как к нему подступиться. Чувствовала себя, как человек, которого бросили в воду, чтобы он сам научился плавать. Но постепенно вошла в 
работу. Поняла, что прежде всего нужно из общего текста выбрать записи по теории чисел, расшифровать их и классифицировать. На это ушла уйма времени. Далее предстояло рассмотреть каждую заметку, выяснить, относится ли она к опубликованным сочинениям Эйлера или содержит ранее неизвестный результат. При этом следовало, как говорил Владимир Иванович, предельно внимательно относиться к каждому слову, каждой формуле и всегда помнить: это Эйлер! Оказалось, что большая часть записей относится к разделу теории чисел, который носит название диофантова анализа. Их я и начала исследовать первыми. А когда все было написано, Владимир Иванович сказал: «Помилуйте, да этого вполне достаточно для диссертации. Кончайте, а остальным будете заниматься потом» [2].

Предзащита кандидатской диссертации Г. П. Матвиевской проходила в отделе истории математики Института истории естествознания и техники в Москве и проходила достаточно драматично. После её доклада выступавшие чуть не поголовно утверждали, что её работа - это не диссертация, что диссертация предполагает решение крупной проблемы, имеющей идеологическое значение, а архив, неопубликованные рукописи - это не то, не годится. Говорили, что диссертант не виноват, что руководитель плохо поставил тему. Тогда и под историю математики старались подвести идеологическую базу. Положение смягчил Василий Павлович Зубов, который твёрдо заявил, что это диссертация. При голосовании счёт оказался в пользу соискательницы, и диссертацию рекомендовали к защите. Когда она рассказала В. И. Смирнову о происшедшем в Москве и добавила, что боится ехать на защиту, он засмеялся и сказал: «Не волнуйтесь, все будет хорошо. Это ведь болтовня, а надо дело делать!».

Защитила работу Г. П. Матвиевская в Москве на учёном совете ИИЕТ 30 декабря 1958 г. Всё, действительно, кончилось хорошо.

В Ленинграде Г. П. Матвиевская вышла замуж за Карима Рахимовича Рахимова, тогда аспиранта Института физиологии АН СССР. Он защитил кандидатскую диссертацию в Ленинграде. В аспирантуру он был направлен из Ташкента и должен был туда вернуться. Позднее он стал доктором биологических наук, профессором, заведовал лабораторией физиологии пищеварения Института физиологии АН УзССР.

Г. П. Матвиевскую распределили в Институт математики АН УзССР имени академика Всеволода Ивановича Романовского, крупнейшего специалиста по теории вероятностей и математической статистике, одного из основателей Ташкентского университета, создателя ташкентской школы теории вероятностей [1]. За 4 года до приезда Матвиевской В. И. Романовский умер, новый директор Сагды Хасанович Сираждинов, образованный,

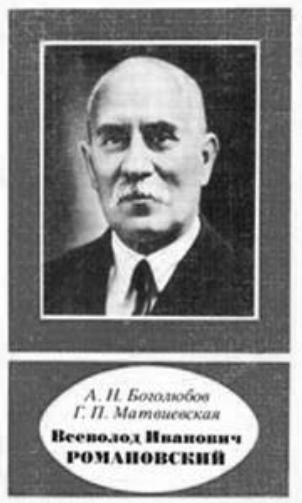
культурный, с широкими интересами, свободно говоривший по-французски, недавно защитивший докторскую диссертацию в МГУ у академика А. Н. Колмогорова, радушно её встретил, но сразу заявил, что ни о каком Эйлере не может быть речи, перед институтом стоят необъятные задачи по исследованию арабской математики, в республике, в Институте востоковедения, накопились горы рукописей, которые фактически не изучались. 
Как оказалось впоследствии, такая ситуация была в мире в целом: средневековая арабская математика оставалась в значительной мере terra incognita, феноменом, не находившим рационального объяснения. Широкий интерес у историков естествознания к средневековым восточным научным документам возник только после Второй мировой войны. Изучение сочинений на арабском и китайском языках, на санскрите дало очень любопытные результаты. Появились серьёзные исследования, в которых пересматривались прежние, заниженные оценки истории науки в странах Востока в средние века.

С. Х. Сираждинов поставил Г. П. Матвиевскую перед кардинальным решением: или переходить к исследованиям истории средневековой арабской математики, или уходить из истории науки. Матвиевская согласилась заняться совершенно незнакомой тематикой, хотя понимала все трудности такого перехода, прежде всего языковые.

О своих мытарствах на новом поприще Галина Павловна сама рассказала достаточно ярко.

«Я согласилась и, таким образом, вступила в область востоковедения. Предстояло начать учиться арабскому языку...

Пришлось начать с нуля. Прежде всего С. Х. Сираждинов предложил собрать все, что есть в литературе, о развитии математики в Средней Азии с древнейших времен. Взялась я за дело с охотой, прочла множество русских и иностранных работ о Средней Азии, истории и истории культуры мусульманского Востока, о средневековой восточной математике. Уже через два года удалось сделать обзор этой литературы. Он вошел в мою первую книгу, которая вышла в 1962 г. под названием: «К истории математики Средней Азии IX - XV веков». Одновременно я начала изучение арабского языка. Это оказалось делом нелегким, потому что тогда в Ташкентском университете на филологическом факультете восточного отделения не было. Пришлось стать самоучкой, хотя я и пыталась найти учителя...» [2]. Укрепил её в этом решении сотрудник Института востоковедения Анатолий Лаврентьевич Казибердов, репатриант из Сирии. Его родители - донские казаки, но сам он родился в Сирии, и арабский язык ему был родной. Он твёрдо заявил: «Берите учебник и учите!». Это были замечательные слова, вселившие уверенность.

«Следуя умному совету, я взяла учебник арабского языка Ковалева и Шарбатова и принялась его штудировать. Труднее всего было вначале, когда учила алфавит. Повторяла его постоянно, даже сидя на заседаниях ученого совета. Постепенно освоила арабскую графику, научилась писать и начала учить грамматику.

А потом - это было в 1961 г. - в Ташкент приехал в командировку Борис Абрамович Розенфельд, в то время уже ставший авторитетом как историк математики и арабист. Адольф Павлович Юшкевич привлёк его к этому делу, когда он жил в Баку и преподавал в университете геометрию. Борис Абрамович был человеком энергичным, смелым, с языками справлялся хорошо и тема его очень заинтересовала. Он быстро освоил арабский язык в той мере, чтобы понимать математический текст. В Баку он опубликовал свои первые переводы. Потом переехал в Коломну, где у него появились первые ученики, а затем стал сотрудником ИИЕТ. Вместе с Адольфом Павловичем они начали объединять всех, кто проявлял интерес к арабской математике. Заслушивались доклады на заседаниях сектора и конференциях, представлялись к печати работы авторов из разных городов. 
Появление Бориса Абрамовича в Ташкенте послужило для нас внушительным толчком. Когда Сираждинов познакомил меня с ним, он сразу спросил: «Арабский язык учите?». Я ответила: «Учу». Он сказал: «Распишитесь поарабски”. Я не была к этому готова, растерялась, но худо-бедно расписалась. Он посмотрел и говорит: «Пойдет. Я сейчас дам Вам текст, и Вы беритесь за его перевод. По ходу дела усовершенствуетесь». Так вот, с тех пор я твердо уверена, что самый лучший метод научить человека плавать - это просто бросить его в воду. Убедилась на собственном опыте.

Арабским текстом, который я получила, был изданный в Хайдарабаде «Трактат о соизмеримых и несоизмеримых величинах» математика X - XI вв. Ибн ал-Багдади. Как и в других хайдарабадских изданиях, текст напечатан по рукописи, без всяких пояснений. Трактат представляет собой комментарий к Х книге «Начал» Евклида, самой трудной книге этого сочинения. Чтобы сделать осмысленный перевод, мне потребовалось, прежде всего, разобраться в евклидовой теории квадратичных иррациональностей, изложенной с помощью геометрии. Кроме того, понять содержание оказалось нелегко, потому что в средние века не существовало привычной для нас математической символики: вместо знаков математики употребляли слова. Нужно было, поэтому, сделанный перевод еще, так сказать, “перевести” на современный математический язык.

К счастью, по содержанию мой трактат оказался очень интересным. Билась я над ним долго, но в конце концов удалось хорошо понять его и прокомментировать. А вот по форме перевод выглядел плохо. Сказывалось недостаточное знание грамматики. И здесь мне очень повезло: я познакомилась с арабистом, закончившим МГУ, - Беллой Яковлевной Ошерович, которая некоторое время работала в Институте философии АН УзССР, а позже переехала в Алма-Ату. Она заинтересовалась мной, посмотрела перевод, поохала, а потом дала мне несколько уроков и привела, таким образом, мой арабский язык в порядок.

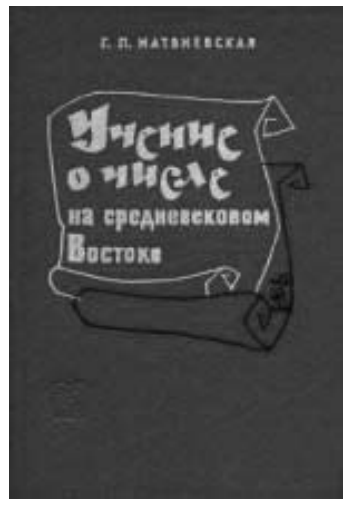

О трактате Ибн ал-Багдади я сделала несколько докладов - в Ленинграде на конференции арабистов и в Москве на Международном конгрессе математиков в 1966 г. Потом перевод был опубликован.

За этим последовали другие арабские трактаты о теории квадратичных иррациональностей. Их переводы вошли в мою книгу «Учение о числе на средневековом Ближнем и Среднем Востоке», которая вышла в 1967 г. [3]

Тема исследования оказалась настолько интересной, что захотелось выяснить, какой была судьба этого учения в Европе, куда арабская математическая литература проникла в ХП в. Во время командировок в Москву и Ленинград я познакомилась с латинскими средневековыми сочинениями, которые хранятся в отделах редкой книги центральных библиотек. Этот материал вошел в вышедшую в 1971 г. книгу «Развитие учения о числе в Европе до XVII века» [4] и в докторскую диссертацию («Учение о числе в средние века»), которую я защитила в 1968 г.

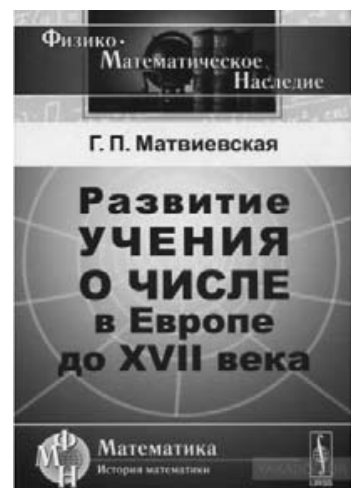


В то время вопрос о характере «арабской» математики обсуждался очень широко и пересматривалась ее оценка. К середине XX в. укоренилось мнение, что она носила сугубо прикладной характер, что арабы успешно разрабатывали новые вычислительные приемы, а что касается теоретического наследия древних греков, то они его вообще не освоили. Заслугу их видели в том, что они перевели труды греческих классиков на арабский язык, сохранив их таким образом от забвения, а затем передали их в Европу, где эти труды были осмыслены и послужили стимулом быстрого развития математической теории. Но после войны появились переводы на европейские языки неизвестных раньше арабских сочинений, которые опровергали эту точку зрения. Постепенно пробел в знаниях об «арабском» периоде истории математики стал заполняться и появилась возможность оценить его более справедливо. Это сделал А. П. Юшкевич в своей книге «История математики в средние века», которая вышла в 1961 г. и много раз переиздавалась на разных языках. Она вызвала большой интерес и явилась сигналом к расширению исследований. Моя работа шла в этом русле. Мне удалось показать, что ученые стран Ближнего и Среднего Востока не только хорошо поняли все тонкости античного учения о числе, но и существенно его развили» [2].

Это была ещё одна, после Эйлера, вершина, которую пришлось преодолеть Г. П. Матвиевской на пути обретения профессионального призвания. И путь к ней был даже более трудным, чем путь к Эйлеру. И её открытия на этом пути получили профессиональное признание в отечественном и международном сообществах историков науки.

По моей субъективной оценке, одной из высших точек этого периода творческой деятельности Г. П. Матвиевской стало проведение в 1983 г. в Ташкенте и Хиве международной конференции, посвященной 1200-летию великого математика Аль-Хорезми. Это мероприятие было проведено на самом высоком государственном уровне. В нём участвовали востоковеды, историки естествознания и техники из зарубежных стран и всех регионов Советского Союза. Было интересно и познавательно. Мне со временем пришлось участвовать во многих конференциях и конгрессах в СССР и за рубежом. Возможно, по относительной тогда моей молодости и восторженности, по масштабам впечатлений от Средней Азии я не могу сравнить эту конференцию с другими, даже более значимыми в научном плане, в особенности по искренности и заинтересованности коммуникаций. На конференцию я попал, скорее всего, по протекции 3. К. Соколовской. Моя деятельность в знаменитой серии «Научно-биографическая литература» только начиналась. Но в сообществе историков науки Института истории естествознания и техники я уже начал адаптироваться отчасти благодаря моему киевскому заведующему отделом Ю. А. Анисимову, авторитет которого в ИИЕТе был велик. Директор ИИЕТа член-корреспондент АН СССР С. Р. Микулинский уже до этого отметил полезность моих рецензий на коллективные монографии института. Историков математики я фактически не знал, кроме С. С. Демидова, который поддерживал отношения с историками математики в Киеве и впоследствии защитил здесь докторскую диссертацию. Заметное впечатление на меня произвёл на конференции в Ташкенте Б. А. Розенфельд, тем более в ярком ореоле молодых академиков-математиков из Баку, инфицированных Розенфельдом интересом к истории математики. Я укрепил свое знакомство с Борисом Старостиным, которое 
оценил гораздо позднее, фактически на всю жизнь подружился с замечательным по человечности Аликом Володарским.

Успехи Г. П. Матвиевской в истории средневековой математики удалось закрепить в прекрасных книгах «Научно-биографической серии», некоторые из них удалось переиздать в XXI веке [5-8].
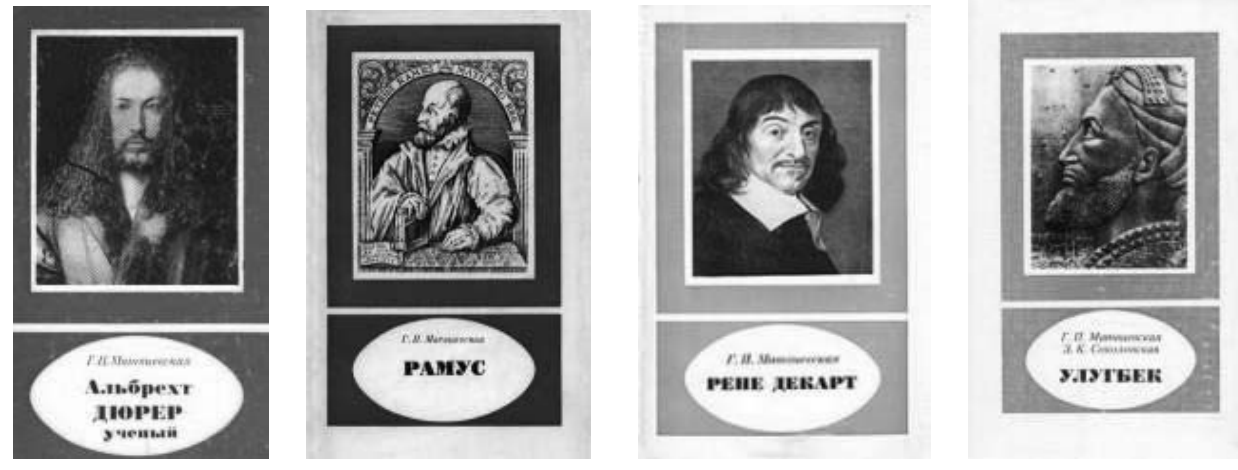

Г. П. Матвиевская была счастлива, что ей с Е. П. Ожиговой удалось подготовить книгу о их учителе академике В. И. Смирнове, в которую вошли статьи о его научной деятельности и воспоминания многих людей, работавших и общавшихся с ним. Книга вышла под редакцией академика О. А. Ладыженской в трудном 1994 г. очень малым тиражом. Матвиевская добилась, чтобы вышло второе её издание [9].

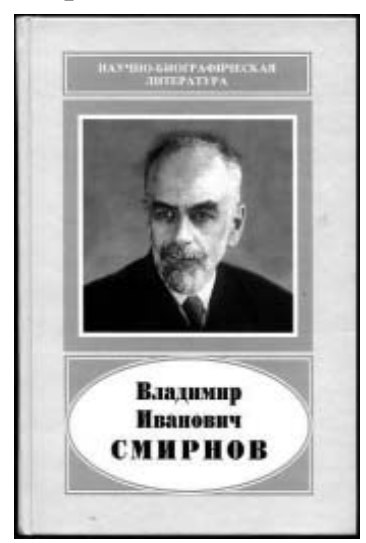

Драматический накал творчества Галины Павловны не только не спал в зрелом возрасте, но, напротив, вырос в годы распада Союза. Об этом опять её собственными словами: «Новый период наступил и для меня: я оказалась в Оренбурге. Это произошло естественно, потому что там жили мои родители.

Отец сорок лет преподавал в Оренбургском пединституте, был профессором, заведовал кафедрой истории СССР и вел большую научную работу. По материалам богатейшего архива Оренбургской области он изучал историю Оренбургского края и русско-казахские отношения в XVIII - XIX вв. В архиве хранятся огромные собрания документов этого периода, отражающие процесс освоения и изучения края и политику России в отношении Казахстана и Средней Азии. Отец был знатоком этих материалов. На основе их исследования он написал около 150 работ, выходивших и в центральных журналах, и в трудах разных конференций, и отдельными изданиями.

У родителей провела детство моя дочь. Школу она кончила в Ташкенте, училась в Ленинграде, как и я, на математико-механическом факультете ЛГУ, потом кончила аспирантуру в Киеве (у Алексея Николаевича Боголюбова), а оттуда вернулась в Оренбург: дедушка и бабушка нуждались в поддержке. С тех пор она преподает математику в политехническом институте, который теперь стал Оренбургским государственным университетом.

В 1987 г. мой отец умер. Дочь, выйдя замуж, вскоре овдовела и осталась одна с бабушкой, которая сильно болела. В общем, в 1993-1994 гг., в это сложное время, наша семья оказалась в очень трудном положении. Нужно было что-то 
делать. Муж сказал: «Придется тебе ехать к ним. Сюда будешь приезжать, а там видно будет». Так и решили.

В Оренбурге ректор пединститута предложил мне читать у них лекции. Я согласилась, хотя и не была уверена в успехе: ведь раньше преподавать мне почти не приходилось.

Так я стала профессором пединститута, вскоре преобразованного в Оренбургский государственный педагогический университет (ОГПУ). Но фактически жила одновременно в Оренбурге и в Ташкенте, потому что ездила туда регулярно раз в три-четыре месяца. Это, конечно, давалось нелегко, но другого выхода не было. Там продолжала работать в Институте математики. Вместе с моей сотрудницей Р. И. Мухамедхановой написали книгу о нашем институте, которая вышла в Ташкенте в 2001 г. В 2000 г. меня избрали академиком Академии наук Узбекистана.

А в 2001 г. заболел и умер муж. Он собирался переехать к нам, но все откладывал, не хотел оставлять работу. Ведь он был физиологомэкспериментатором, руководил научно-исследовательской лабораторией, с ним работало много людей - его учеников. Потом все же стал готовиться к переезду, но не успел. Мои поездки в Ташкент закончились.

В Оренбурге, помимо преподавания и руководства аспирантами, я занялась краеведением. Отец мне всегда говорил: «Ты не представляешь себе, какой интересный Оренбургский край, какая интересная у него история». Теперь я это вполне оценила.

Началось с того, что подготовила к печати рукопись книги отца о замечательном оренбургском ученом XVIII в., первом члене-корреспонденте Петербургской академии наук Петре Ивановиче Рычкове. Он взялся писать ее вместе с А. В. Ефремовым из Бугульмы, но закончить не успел. В 1988 г. я увезла рукопись в Ташкент, переписала ее, выверила ссылки на литературные источники и на документы оренбургского архива.

Книга вышла в 1991 г. в издательстве «Наука», в научно-биографической серии. А я приобщилась к оренбургской тематике и смогла стать краеведом. Очень этому рада, потому что иначе было бы скучно.

Краеведением мы занимаемся вместе с дочерью, Инной Каримовной Зубовой. Она проследила по документам судьбу потомков П. И. Рычкова, опубликовала серию статей о них» [2].

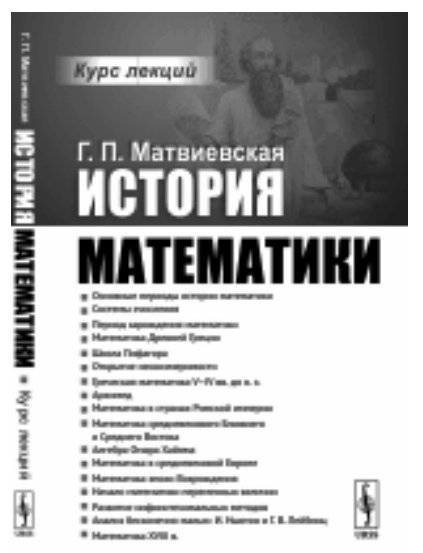

Я рассматриваю этот этап деятельности Галины Павловны как вполне самостоятельный, когда она обрела новые качества своего развития. Прежде всего ей пришлось заняться преподаванием математики в университете. В её возрасте это было непросто, но получилось, и на этой основе появились даже её учебники, например, курс лекций по истории математики [10]. Она продолжила вместе с аспирантами тему разработки архива Л. Эйлера. Были опубликованы её новые книги, написанные на принципиально ином материале, тоже архивном, «оренбургском», - это научно-биографические книги о В. И. Дале [11] и Я. В. Ханыкове [12]. Она стала писателем (она была им давно), членом Союза писателей России, её литературное творчество получило признание: она лауреат премии «Оренбургская лира» и всероссийской премии 
«Капитанская дочка». Всякий, кто захочет познакомиться с её замечательными историческими миниатюрами из истории культуры Оренбурга (например, «Дом на набережной Урала», «Сады Оренбурга» и многие другие), может найти их в Интернете. Но самое главное - она завершила дело отца, опубликовав его незавершенную книгу о первом члене-корреспонденте Петербургской академии наук Петре Ивановиче Рычкове.

Мечта почти любого творческого человека - оставить память о родителях, но не всякому это удаётся сделать из-за суеты и мелочей жизни, которые нарастают к её концу. Галине Павловне это удалось и наградой ей стала долгая, насыщенная трудами и проблемами жизнь.
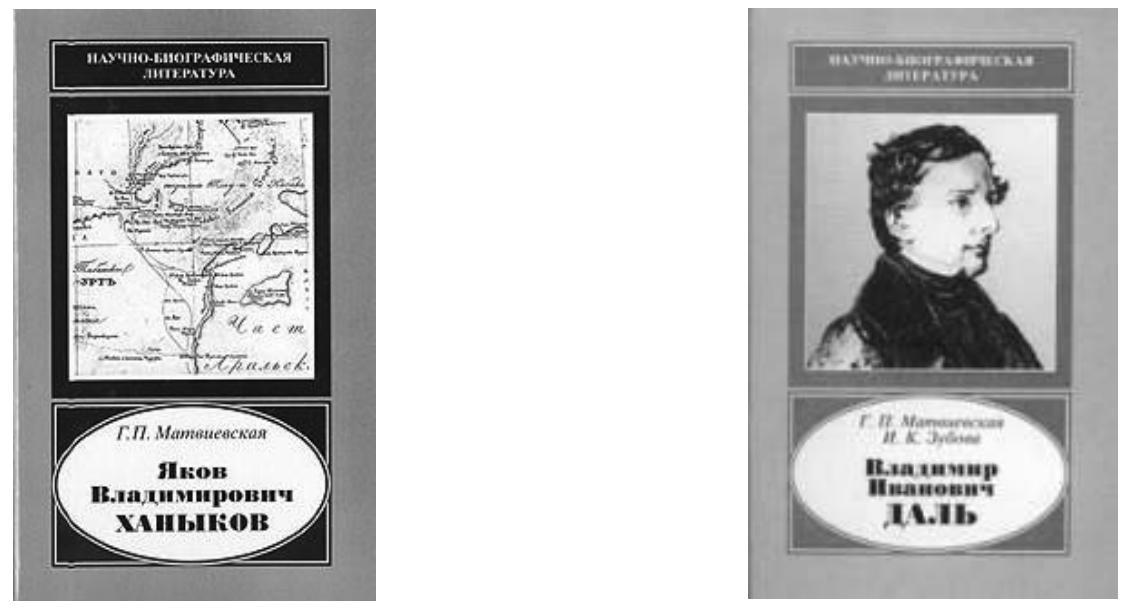

Я никогда не был близко знаком с Галиной Павловной. Мне кажется, что и виделся с ней только во время конференции в Ташкенте. Даже с её дочерью, тогда юной красавицей, которая была у нас в Киеве аспиранткой А. Н. Боголюбова я встречался чаще. Но я всегда полагал, что мы с ней из одного профессионального сообщества. Кроме того, она была близкой подругой Зинаиды Кузьминичны Соколовской, которая вместе с академиком А. Л. Яншиным вовлекли меня, уже после защиты докторской диссертации по философии науки, в новый виток саморазвития на почве замечательной серии «Научно-биографическая литература». Я им крайне признателен за это, как, впрочем, и Галина Павловна. Поэтому мне было важно узнать, что идею книги о Декарте подсказала Г. П. Матвиевской 3. К Соколовская. Я, как имеющий и философское образование, могу засвидетельствовать, что понимание философской системы Декарта значительно выросло от представления о нём как математике в книге Матвиевской.

Выводы. Находясь в одном профессиональном сообществе, каждый из нас реализует себя в меру данных нам способностей, талантов и умений. Поэтому нет особого смысла сравнивать себя с Галиной Павловной или, тем более, с Василием Павловичем Зубовым, который помог ей сделать первые шаги на пути призвания. Главное здесь в том, чтобы не пропустить в себе то, что ты можешь, и не запустить, потерять свои возможности.

\section{References}

1. Bogolyubov, A. N., Matvievskaya, G. P. (1997). Vsevolod Ivanovich Romanovskiy (Scientific and Biographical Series). 1879-1954, Moskow, Nauka, 157 p. (in Russian). 
2. Interview with G. P. Matvievskaya. Arhiv istorii nauki i tehniki. Issue III, Moskow, Nauka, 2007, pp. 443-472. Publikatoryi S. S. Ilizarov, M. V. Mokrova; Republikatsiya:; Republikatsiya: Onoprienko, V. I. (2011). Science is a vocation. Interview book. Kiev: Inform.-analit. agentstvo, pp. 41-74 (in Russian).

3. Matvievskaya, G. P. (1967). The doctrine of numbers in the medieval East. Tashkent: Fan, 344 p.; 2rd ed., Moskow, Librokom, 2012, 346 p. (in Russian).

4. Matvievskaya, G. P. (1971). The development of the doctrine of numbers in Europe until the 17th century. Tashkent: Fan, 231 p.; 2rd ed., Moskow, URSS, 2020, 232 p. (in Russian).

5. Matvievskaya, G. P. (1976). Rene Descartes. Moskow, Nauka, 272 p. (Scientific and Biographical Series); 2rd ed., Moskow, Librokom, 2014, 272 p. (in Russian).

6. Matvievskaya, G. P. (1981). Ramus. 1515-1572. Moskow, Nauka, 152 p. (Scientific and Biographical Series) (in Russian).

7. Matvievskaya, G. P. (1987). Albrecht Durer - Scientist. 1471-1528. Moskow, Nauka, 240 p. (Scientific and Biographical Series); 2rd ed., Moskow, Librokom, 2013, 248 p.; 3rd ed., M.: URSS, 2019, 248 p. (in Russian).

8. Matvievskaya, G. P., Sokolovskaya, Z. K. (1997). Ulugbek. 1394-1449. Moskow, Nauka, 152 p. (Scientific and Biographical Series) (in Russian).

9. Vladimir Ivanovich Smirnov. 1887-1974, ed. by O. A. Ladyizhenskaya, Moskow, Nauka, 1994, 288 p. (Scientific and Biographical Series); 2rd ed., Moskow, Nauka, 1996, 326 p. (Scientific and Biographical Series) (in Russian).

10. Matvievskaya, G. P. (2019). The History of mathematics. Lecture course. Moskow, URSS, 208 p. (in Russian).

11. Matvievskaya, G. P., Zubova, I. K. (2002). Vladimir Ivanovich Dal. 1801-1872. Moskow, Nauka, 224 p. (Scientific and Biographical Series) (in Russian)

12. Matvievskaya, G. P. (2006). Yakov Vladimirovich Hanyikov. 1818-1862. Moskow, Nauka, 200 p. (Scientific and Biographical Series) (in Russian).

Received 14.01.2020

Received in revised form 27.01.202m

Accepted 13.02.2020 